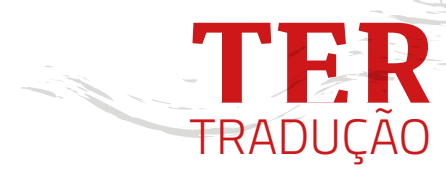

\title{
BLACKING, JOHN POR UMA ANTROPOLOGIA DO CORPO
}

dx.doi.org/10.11606/issn.25253123.gis.2020.171003

ORCID orcid.org/0000-0003-4134-9543

ORCID orcid.org/0000-0002-9798-0644
Blacking, John. 1977. Towards an Anthropology of the Body. In The anthropology of the body. London: Academic Press, 1-28.

\section{TRADUÇÃO: ÉRICA GIESBRECHT}

Campinas, SP, Brasil, 13087-500

egiesbrecht@gmail.com

\section{LAIIS SALGUEIRO}

Universidade Federal do Estado do Rio de Janeiro, Rio de Janeiro, RJ, Brasil, 22290-240 - clappgac@gmail.com

\section{FERRAN TAMARIT REBOLLO}

Universidade Federal do Estado do Rio de Janeiro, Rio de Janeiro, RJ, Brasil, 22290-240 - secensinoppgm@unirio.br

\section{APRESENTAÇÃo}

A bibliografia produzida por John Blacking foi vasta e essencial para a formação da etnomusicologia a partir do século XX. Com uma história de vida marcada pela carreira de pianista, participação junto ao exército britânico em operações em ex-colônias e interesse pela antropologia, anteriores ao início do trabalho acadêmico', Blacking produziria suas primeiras pesquisas sobre os Venda, ainda na década de $1950^{2}$.

1. Sem desmerecer totalmente sua contribuição para o nascimento dos estudos sobre música africana, o envolvimento de Blacking com as administrações coloniais ainda é objeto de controvérsia e crítica dentro da chamada "Musicologia Africana", que desde agendas abertamente pós-coloniais reclama por mais protagonismo e agência dos próprios acadêmicos autóctones do continente (Mapaya, 2018). Por outro lado, autores como Agawu (2003) destacam como a densidade etnográfica do empreendimento de Blacking com os Venda se encontra limitada pela pouca ênfase em teorias e epistemologias nativas no momento de desenvolver sua complexa análise estrutural da música propriamente.

2. Para uma biografia de John Blacking mais detalhada ver: Travassos, 2007. 
Seu estudo junto a essa sociedade se estendeu ao longo de 30 anos, entre seu Doutorado na Universidade de Cambridge e seu trabalho como professor, inicialmente desenvolvido na Universidade de Johanesburgo e posteriormente na Queen's University, em Belfast, onde lecionou até o fim de sua vida. A inovação trazida por Blacking para o campo da etnomusicologia da época estava na prioridade conferida ao trabalho etnográfico, em lugar do desenvolvimento de teorias etnomusicológicas gerais como fizeram seus colegas contemporâneos. Suas fortes ligações com a Society for Ethnomusicology (SEM) e o com International Council for Traditional Music (ICTM) o tornaram bastante conhecido entre etnomusicólogos, porém raramente lido por antropólogos, até mesmos britânicos, mais interessados em questões como sistemas de parentesco, sistemas políticos, rituais ou dramas sociais no que concernia aos estudos africanos.

A recíproca, porém, era inversa, visto que a obra de Blacking dialoga com o estrutural-funcionalismo inglês e com reflexões de Levis-Strauss e Chomsky (ver Byron 1995). A questão de fundo que o movia, no entanto, era outra. Partia da premissa de uma natureza da musicalidade humana e primava por conhecer sua relação com a linguagem, com a organização social, com a construção de afetividades e com os processos de cognição da cultura.

No pensamento de Blacking, a capacidade musical inata do ser humano, tal qual a fala, necessitaria de interações sócio-afetivas para ser desenvolvida. E essa capacidade, assim como diversas outras, está no corpo.

Em 1973, Blacking organiza um simpósio sobre antropologia do corpo, para fomentar a discussão sobre essas capacidades humanas, a partir do qual surge a célebre coletânea The Anthropology of the Body (1977). "Por uma Antropologia do Corpo", artigo que agora apresentamos traduzido, compõe essa coletânea e instiga os antropólogos ao estudo aprofundado dos afetos enquanto fenômenos simultaneamente subjetivos e externalizados, capazes de mediar relações sociais e de exercer efeitos sobre ações e compreensões de mundo.

Blacking propõe que categorias como mental e corporal, biológico e cultural, comunicação verbal e não-verbal são indissociáveis e são capacidades corpóreas. Retomando a noção de Durkheim de sociedade como conjunto de forças ativas, opõe-se à dicotomia entre natureza e cultura: as habilidades humanas são ao mesmo tempo inatas e adquiridas, visto que são pertinentes ao corpo humano, mas só se desenvolvem à medida que esses seres, biologicamente equipados, compartilham experiências entre seus fellow humans. Em outras palavras, o ser humano depende tanto das habilidades corpóreas quanto das sociais. 
Provavelmente os maiores desafios desta tradução se deveram à especificidade das reflexões de Blacking, que o levaram a criar termos capazes de expressar suas ideias na língua inglesa. Fellow-feeling, que aqui traduzimos por "empatia" exprime ao mesmo tempo um sentido de fraternidade e de reconhecimento intersubjetivo da humanidade dos outros. Fellow man ou Fellow human são semelhantes, companheiros de uma humanidade compartilhada, companheiros de espécie. São diferentes de mankind, que traduziríamos como "espécie humana", porque o termo biológico não abarca a noção de companheirismo³.

A inovação deste artigo não está exatamente em afirmar que os seres humanos são biologicamente sociais, mas em demonstrar que, ainda que nossos corpos sejam biologicamente preparados para o desenvolvimento de inúmeras capacidades, não são humanos enquanto não compartilham experiências entre os membros da espécie. É preciso interagir socialmente para se humanizar.

Por fim, acreditamos que o texto se faz atual para discussões tanto na etnomusicologia como nas áreas da antropologia da dança, do corpo e da performance, por pleitear o entrelaçamento entre sons, corpos e culturas para além da dicotomia homem e natureza. Esperamos assim contribuir com discussões atuais e apresentar como elas eram desenvolvidas por Blacking em outra época e contexto.

\section{REFERÊNCIAS BIBLIOGRÁFICAS}

Agawu, Victor Kofi. 2003. Representing African music: postcolonial notes, queries, positions. New York: Taylor and Francis Books.

Byron, Reginald. 1995. The ethnomusicology of John Blacking. In Music, culture \& experience, John Blacking Chicago, 1-28. Chicago: The University of Chicago Press.

Mapaya, Madimabe Geoff. 2018. Dipsticking the study of indigenous african music from the john blacking era into the 21st century. In John Blacking and Contemporary African Musicology; Reflections, Reviews, Analyses and Prospects, M. Mapaya and N. Mugovhani, eds. , 113-128. Cape Town: Centre for Advanced Studies of African Society.

Travassos, Elizabeth. 2007. John Blacking ou uma humanidade sonora e saudavelmente organizada. Cadernos De Campo, vol. 16, n 16: 191-200.

3. Agradecemos a Charles Exdell, etnomusicólogo estadunidense, que nos ajudou gentilmente com a tradução e entendimento desse vocabulário. 


\section{POR UMA ANTROPOLOGIA DO CORPO}

É através do meu corpo que eu entendo outras pessoas, assim como é através do meu corpo que eu percebo as "coisas". o significado de um gesto assim "entendido" não está por trás dele, é misturado com a estrutura do mundo, delineado pelo gesto, e que eu assumo por mim mesmo. 0 significado está disposto em todo o gesto em si. (Merleau-Ponty 1962, 186)

No entanto, é bastante claro que o discurso constituído, como ele funciona na vida cotidiana, assume que o passo decisivo de expressão foi tomado. Nossa visão sobre o homem vai permanecer superficial enquanto deixarmos de voltar a essa origem, enquanto deixarmos de buscar, sob a tagarelice das palavras, o silencio primordial, e enquanto não descrevermos a ação que quebra esse silêncio. A palavra falada é um gesto, e o seu sentido, um mundo. (Merleau-Ponty 1962, 184 apud Poole 1975, 88 e 89)

o que eu entendo por uma antropologia do corpo provavelmente difere consideravelmente dos sentidos atribuídos por outros colaboradores e por aqueles que vieram para participar. Mas apesar de eu começar com citações de Merleau-Ponty que soam fenomenológicas, e embora conversas ambíguas e divididas reforcem mais do que clareiem as diferenças, espero que haja algum consenso sobre a necessidade de se estudar os fundamentos biológicos e afetivos de nossas construções sociais da realidade, mesmo que nem todos concordem que essa seja uma preocupação apropriada dos antropólogos sociais.

Talvez pareça prematuro tentar ir além das contribuições do excelente volume editado por Robert Hinde sobre Non-Verbal Communication (1972) e por Benthall e Polhemus sobre The body as a medium of expression (1975), e presunçoso pensar que nós podemos atingir um grau de desapego e objetividade das forças às quais estamos todos sujeitos. Mas com o desaparecimento da divisão entre natureza e cultura como uma fronteira relevante para nossa disciplina, é legitimo e desejável olhar os meios de expressão do corpo como produtos de processos ambientais e biológicos mais gerais. Também, ao estudar transculturalmente os estados somáticos envolvidos no comportamento e na ação humana, nós seremos capazes de descrever melhor o repertório latente do corpo humano de onde transformações culturais são, enfim, derivadas. 0 tópico merece discussões mais aprofundadas, no mínimo, porque tem algo a oferecer ao crescente número de pesquisadores preocupados com o estudo do comportamento interpessoal: a antropologia fornece um laboratório crucial para suas teorias.

A área de discurso que eu chamo de antropologia do corpo não é um nome novo para a antropologia biossocial ou física, embora deva partir 
do pressuposto de que o comportamento e as ações humanas são funções de organismos com um conjunto único de características da espécie em ambientes social e físico particulares, e que elas são adaptativas no contexto da evolução biológica. Ao reivindicar que as explicações do comportamento humano devem começar com pleno entendimento do corpo como um sistema físico total, eu não estou sugerindo que antropólogos se tornem psicólogos ou fisiologistas. Nossa principal preocupação é com os processos e produtos culturais que são externalizações e extensões do corpo em contextos variáveis de interação social. A divisão da antropologia física e cultural (ou social) já não é mais útil, desde que se tornou claro que a forma do corpo humano é influenciada pela cultura, e que fenômenos aparentemente culturais, como a linguagem, são biologicamente embasados (Lenneberg 1967).

Leslie White defende que a "descoberta" de Tylor da ciência da cultura talvez "um dia tenha tanta importância na história da ciência quanto a teoria heliocêntrica de Copérnico ou a descoberta das bases celulares de todas as formas de vida" (White 1949, 4 e 5). Nós podemos concordar que os padrões da cultura, uma vez criados pelo homem, podem ter uma força e lógica próprias, como um sistema de energia controlada leva a outro, e que eles são mais entranhados do que as forças de produção como influência na ação humana. Mas a visão de White de que "o comportamento humano é uma função da cultura[...] assim como a cultura varia, também varia o comportamento" (White 1949, 403) ignora os fatores biológicos na invenção da cultura, mesmo que se admita que White está se referindo a aspectos conscientes e direcionados do comportamento, os quais eu prefiro chamar de "ação". Isso implicitamente diferencia o homem de outros animais de uma maneira não corroborada pelos fatos. 0 homem não está necessariamente preso a produtos da adaptação cultural assim como as girafas estão presas aos seus pescoços alongados ou os mamutes à sua pelagem espessa; mas nem o comportamento humano se distingue destes animais por uma simples dicotomia cultura e natureza.

O comportamento e ação humana são apenas, em parte, função da cultura e não há evidências para afirmar que, em algum momento da história, o desenvolvimento da cultura, da razão, da linguagem ou a expertise tecnológica tenham liberado o homo sapiens sapiens das restrições, forças e propensões impostas pelas características de sua espécie e pelo processo evolutivo que levou a espécie a ser. A habilidade de transmitir cultura em si não faz o homem diferente das outras espécies, porque muitos outros animais têm algum tipo de cultura. E, apesar do desenvolvimento da cultura parecer ter sido um fator crítico na evolução biológica do homem moderno, nós precisamos postular outros tipos de mudanças biológicas e comportamentais para explicar as qualidades peculiares da cultura humana. 
Isto é, apesar de ter sido argumentado que "o grande tamanho do cérebro de certos hominídeos foi um desenvolvimento relativamente tardio devido a novas pressões seletivas após o bipedismo e o consequente uso de ferramentas" (Washburn e Howell 1960, 49ff) e que "a singularidade do homem moderno é [...] o resultado de uma vida técnico-social que triplicou o tamanho do cérebro, reduziu a face e modificou muitas outras estruturas do corpo" (Ibid.), também pode ser argumentado que a vida técnico-social foi fundada no refinamento das capacidades sensório-motoras bem como no desenvolvimento da caça como modo de vida. Desenvolvimentos especiais na comunicação e na interação dos organismos talvez tenham sido mais cruciais na evolução do homem moderno e da cultura humana do que a extensão da "cultura" animal a um modo de produção: a cooperação na produção pressupõe uma forma humana peculiar de cooperação. Similarmente, a capacidade de fala é uma característica singular da espécie humana biologicamente determinada; mas requer condições sociais específicas para o seu desenvolvimento normal (Lenneberg 1967, 373 e 374). Já que uma faculdade humana biologicamente baseada requer interação social, nós podemos dizer que as condições sociais são também biologicamente determinadas.

Novamente, antropólogos ${ }^{4}$ afirmam que o homem tem uma capacidade genética especial para a cultura, um atributo da espécie sem o qual um organismo não é normal, não é verdadeiramente humano. Se a cultura é até certo ponto biológica, sua realização depende de uma interação social de um tipo certo e na hora certa no desenvolvimento ontogenético do organismo. Privações de sentidos como a cegueira congênita ou a surdez podem inibir ou mudar o curso do desenvolvimento, mas não prejudicam a humanidade do organismo como fazem as privações sociais. Sérias privações de sentido podem interferir no desenvolvimento básico de fatores cognitivos humanos, como o pensamento simbólico e a habilidade de diferenciar e relacionar categorias, como no caso de Helen Keller; 5 mas isso não destrói os mais fundamentais atributos do homem como a educabilidade, plasticidade e empatia.

\footnotetext{
4. Vale lembrar que Blacking dialoga com a Antropologia Social inglesa da década de 1970 [N.T.]. 5. Helen Keller (1880-1968) foi uma escritora e ativista social norte-americana. É citada por Blacking pela repercussão causada por sua história de vida. Foi a primeira pessoa com deficiência auditiva e visual a conquistar um bacharelado nos Estados Unidos. A história sobre como sua professora, Anne Sullivan, conseguiu romper o isolamento imposto pela quase total falta de comunicação tornou-se amplamente conhecida através do roteiro da peça The Miracle Worker, que virou o filme O Milagre de Anne Sullivan (1962). Keller se tornou uma personalidade célebre pelo extenso trabalho que desenvolveu em favor das pessoas com deficiência. Expressava de forma contundente suas convicções tendo sido membro do Socialist Party of America e do Industrial Workers of the World, participado das campanhas pelo voto feminino, direitos trabalhistas, socialismo e outras causas de esquerda. Disponível em: https://www.hki.org [N. T.].
} 
Nosso entendimento sobre o que pode ser chamado sociologia do corpo avançou com Marcel Mauss, Robert Hertz e mais recentemente com Mary Douglas. Eu espero que uma antropologia do corpo esteja apta a incorporar seus insights e técnicas de análise com aquelas dos etólogos e antropólogos biossociais. Assim, Mauss argumenta que "dentro de toda sociedade, todo mundo sabe e deve saber e aprender o que é preciso em todas as condições (Mauss 1936, 384) e Douglas escreve:

\begin{abstract}
o corpo social condiciona o modo como o corpo físico é percebido. A experiência física do corpo, sempre modificada pelas categorias sociais através das quais essa é entendida, sustenta uma visão particular da sociedade. Há uma troca contínua de sentidos entre os dois tipos de experiências corporais de modo que uma reforça as categorias da outra. Como resultado dessa interação, o próprio corpo é um meio altamente restrito de expressão. (Douglas 1973, 93)
\end{abstract}

No entanto, existe mais um problema. Técnicas do corpo não são tão inteiramente aprendidas com os outros, tanto quanto descobertas através dos outros. 0 consenso cognitivo que faz tanto o corpo social como o sócio-físico possíveis não é sempre totalmente percebido ou consciente. Muitas coisas, para as quais a sociedade não tem rótulos, nos acontecem. Uma vez que sustento que o corpo nunca é infinitamente maleável, segue-se que podem haver tensões entre o treinamento e educação das pessoas nas técnicas do corpo e as forças e propensões próprias de seus corpos. Eu ainda gostaria de ir mais longe para dizer que a tensão entre a realidade "interna" e "externa" é um fator crucial na motivação do comportamento e da ação humana, e que a medida de sua influência se encontra nos significados dos sentimentos em qualquer situação dada. Foi a esse tipo de problema que Merleau-Ponty se dirigiu; mas quando Roger Poole critica a fenomenologia por falhar no exame da expressão corporal num contexto histórico, e argumenta com razão que "é de um contexto histórico e ético específico que o indivíduo deriva as possibilidades de expressão do seu corpo" (Poole 1975, 95), deve ser também relembrado que cada corpo na história é também um evento na história do corpo, e que sua constituição genética e seu lugar na evolução biológica exercem algumas limitações em sua liberdade de agir.

O estudo da qualidade dos sentimentos humanos e da estrutura dos afetos se tornou uma prioridade numa antropologia do corpo. Depois de extensas pesquisas sobre o afeto, Silvan Tomkins resumiu a proposição em 1964:

(1) Afetos são os motivos primários do homem; (2) afetos não são respostas obscuras, intestinais e privadas, mas respostas faciais que comunicam e motivam [...] (3) essas comunicações são mais facilmente entendidas do que 
mal-entendidas; (4) afetos têm efeitos profundos na cognição e na ação, e de modo inverso, ambos, cognição e ação têm profundos efeitos no afeto. Assim sendo, o problema da medição envolve a medição tanto da consciência do afeto pelo observador e pelo self quanto a medição do impacto do afeto na cognição e ação, e a medição do impacto da cognição e ação no afeto (Tomkins e Izard 1966, vii, grifo do autor)

Cientistas sociais frequentemente descrevem relacionamentos em terminologias afetivas, ou tendem a assumir que quanto mais as pessoas se associam, mais elas se importam umas com as outras, mas em toda a literatura sobre parentesco, casamento e religião, há bem pouca informação precisa sobre se apaixonar em diferentes culturas, sobre os sentimentos dos cônjuges um para com o outro, ou sobre experiências das pessoas em êxtase, transcendência ou dançando alegremente. o sentimento é o catalisador que transforma o conhecimento adquirido em entendido, e assim adiciona a dimensão do comprometimento à ação. É o mediador entre o corpo e o que é genericamente chamado de mente, porque fornece o valor que separa aquilo que deve ser compartilhado e conceitualizado daquilo que deve permanecer como sensação privada. A mente humana é basicamente uma expressão dos sentimentos do corpo social (social, em termos biológicos em vez do sentido nominal). Dizer que tais estados somáticos não podem ser descritos, ainda que por analogia, é uma derrota assumida.

Primeiramente, técnicas de investigação de estados emocionais estão se tornando cada vez mais sofisticadas, e não podem mais ser encobertas ou ignoradas nos detalhados estudos da interação humana (ver, por exemplo, Ekman, Friesen e Ellsworth 1972, Ekman 1975), e em segundo lugar, observações da comunicação não verbal dos outros podem revelar padrões de comportamento que são importantes nas sequências de interação, mas que nem o observador nem os atores conheceram. Em terceiro lugar, desde que seja possível que um observador se relacione com os objetos humanos de sua investigação de uma maneira que não é possível na ciência natural, o corpo do observador pode servir como uma ferramenta de diagnóstico. Meu conhecimento é tanto gerado quanto restrito pelas percepções e processos cognitivos da minha sociedade, mas através do meu corpo eu posso, às vezes, entender mais do que eu sei através da minha ou de outra sociedade, porque eu tenho mais experiência do que rótulos sociais. Deveria, portanto, ser nossa tarefa, como antropólogos, experimentar os corpos dos Outros através de nossos próprios corpos e aprender mais sobre alguns estados somáticos que nós podemos entender, mas sobre os quais sabemos pouco além das descrições verbais inadequadas da nossa sociedade. Sugiro que nós podemos e devemos ser racionais sobre os sentimentos, e que essa subjetividade consciente pode ser cientificamente produtiva. 
Não se pode assumir que os estados somáticos permaneçam necessariamente neutros até que alguma interpretação social ou valor seja atribuído a eles. Alguns estados somáticos talvez tenham qualidades intrínsecas que comandam a atenção, expandem a consciência e realmente sugerem sua própria interpretação sobre eles. Estados alterados de consciência são experiências comuns para muitos povos oprimidos no mundo, e muitas vezes esses estados parecem adiar em vez de promover uma resposta positiva à situação política. Mas alguns estados somáticos também podem ajudar a fazer emergir uma consciência coletiva generalizada, e a partir desses sentimentos, em vez de avaliações racionais da situação percebida, uma consciência de classe mais específica pode se desenvolver e servir de base para ações políticas. Situações similares podem ocorrer quando pessoas são afetadas por experiências musicais não-referenciadas: porque a música pode criar um mundo de tempo virtual no qual as coisas não estão mais sujeitas ao tempo e espaço, pode fazer as pessoas mais conscientes dos sentimentos que elas experienciaram, total ou parcialmente, e então restaurar as condições de empatia, consciência do corpo, educabilidade e plasticidade que são básicas para a sobrevivência da espécie. O que é preciso saber é se é o mesmo tipo de estado somático que provoca esses diferentes resultados e até que ponto sua eficácia depende de conotações e variações culturais em situações sociais. Ou existem diferentes tipos de estados somáticos? Existem evidências de que alguns estados envolvem ambos os hemisférios do cérebro, e particularmente o hemisfério direito. Talvez, se o esquerdo for eliminado, tenhamos um estado em que o indivíduo se torna como um autômato, mas enquanto ambos os hemisférios estiverem trabalhando com energia igual teremos um estado mais iluminado e criativo.

Os mais dramáticos desses estados somáticos são o transe e o êxtase, e eles parecem depender muito da presença real ou imaginada dos outros. Abraham Maslow argumenta que essas experiências são parte integrante do corpo humano, o que chama de experiência máxima. "O homem tem uma natureza superior e transcendente e isso é parte da sua essência, ou seja, sua natureza biológica como membro da espécie que evoluiu" (Maslow 1970, xvi). "Valores espirituais têm significados naturalísticos [...] les não são posses exclusivas de igrejas organizadas" (Op. cit, 4). Em outras palavras, as pessoas podem ser "surpreendidas pela alegria" e receber a graça divina em toda sua plenitude sem nenhuma preparação ou explicação teológica geralmente considerada necessária para que a experiência seja definida enquanto tal.

Não é necessário mencionar evidências etnográficas para sustentar a visão de que as sociedades ao redor do mundo atrelam valores supremos a estados somáticos transcendentais e experiências de ressonância corporal, ou verdadeiros sentimentos de empatia. A natureza nos afeta 
quando nós "pertencemos" ao céu ou à grama e podemos nos identificar com as árvores e flores. Uma festa bem-sucedida é aquela em que a conversação flui sem esforço porque as pessoas são sensíveis com os humores e interesses de cada um. Num bom seminário, todos os presentes se envolvem fisicamente, ficam exaltados e geralmente surpresos pelas observações brilhantes que saem de suas bocas. o fazer musical é mais excitante quando os performers e os instrumentos são como um ao serem tocados; e isso é contagiante e sentido pela plateia. Pinturas e esculturas são apreciadas quando elas deixam de ser objetos deixados no espaço, quando o observador fica "perdido" no ritmo das suas cores ou formas e superfícies. O amor é mais arrebatador quando ele transcende a obviedade sexual, quando uma excitação genital subsidia e dá caminhos para uma consciência mais geral de todo o corpo, e o corpo é levado a um movimento de contraponto, do qual o coito é apenas uma fase. Estados somáticos similares parecem ser induzidos por bebidas, drogas ou jejuns; mas eu penso que seria mais correto dizer que tais dispositivos não induzem ao estado tanto quanto ajudam a suprimir as regras culturais que inibem sua expressão natural.

Dada a maleabilidade do organismo humano, talvez seja surpreendente que as pessoas não sejam mais diferentes e que estados alterados de consciência não gerem mais ações individualmente autocentradas. Por essa razão, entre outras, é necessário investigar como os estados somáticos diferem, e em que medida, se em alguma, eles são realmente compartilhados. Isto é, tanto através da medição do corpo quanto através da observação do comportamento e do registro de considerações verbais sobre ele ou a ele relacionadas, nós precisamos analisar estados similares em diferentes sociedades e através de uma comparação transcultural, distinguir entre elas. Nós precisamos saber tanto como o cérebro e o sistema nervoso estão trabalhando quanto o que as pessoas dizem e fazem em relação a esses estados. Como alguns caminham pelo fogo e queimam o pé e outros não, como alguns devotos derramam sangue com facas e alfinetes e outros não, como alguns "estados de transe" são criativos e outros levam a pessoa a um estado autômato? Terapias envolvendo música e a dança são eficazes porque certos padrões de som e movimento podem afetar automaticamente 0 corpo humano ou porque a intensidade da situação social associada gera energia e/ou libera mecanismos inibitórios? Nós precisamos saber quais estados são ou podem ser compartilhados conscientemente, para que dois ou mais corpos estejam conscientes um do outro ao experienciarem estados similares. Tais estados são comuns em "experiências religiosas e em música e dança, e sua precisão é geralmente validada por um diagnóstico preciso de dor e doença derivadas de sentimentos correspondentes no corpo de quem as diagnostica. 0 que impede as pessoas de desenvolverem diferenças ilimitadas não é uma simples convenção social, mas também a ligação dos sistemas sensoriais e comunicativos da espécie" (Cf. Eibl-Eibesfeldt 1971) 
A primeira premissa de uma antropologia do corpo é, portanto, que a sociedade "não é um ser nominal criado pela razão, mas um sistema de forças ativas" (Durkheim 1961, 495). A sociedade humana não é apenas como um simples organismo: ela é um fenômeno biológico, um produto do processo evolutivo. Assim devemos falar não da espécie humana, mas da espécie humana e de companheiros humanos. Coperação e interação social não são consequências do contrato racional ou de hábitos aprendidos durante um longo período da infância dependente da mãe: elas são programadas biologicamente e são condições necessárias para o crescimento de distintos organismos humanos. A referência de Durkheim a um "sistema de foças ativas" é certamente mais do que uma afirmação sobre a natureza da sociedade como um fato social que tanto limita quanto cria comportamentos; ela implica poderes de consciência sensorial, de ressonância e de comunicação entre as partes individuais do organismo social. Isso fornece a base de uma ciência da sociedade ao sugerir que os seres humanos estão destinados a compartilhar estados somáticos e que essa característica específica da espécie é necessária para o desenvolvimento de seus processos e capacidades cognitivas.

Apesar da esmagadora evidência de que pessoas em todas as sociedades compartilham estados somáticos entre pares e às vezes entre um considerável número de pessoas, e apesar de toda a música, literatura e experiência cotidiana sobre o amor (ou talvez devido a estes dados), os sucessores de Durkheim geralmente evitaram os aspectos aparentemente místicos de sua teoria. Ao invés de estudarem as sociedades como elas realmente são, como sistemas de forças ativas, antropólogos e sociólogos as têm estudado como os atores e cientistas sociais dizem que elas são: a solidariedade biológica fundamental dos grupos não tem sido analiticamente distinguida de sua solidariedade nominal. De fato, certos tipos de comportamento social têm sido referenciados como expressões de "instinto de rebanho", e assim alienados do significado e propósito humanos, como se a solidariedade biologicamente induzida fosse apenas um fator negativo em assuntos verdadeiramente humanos. Distinções analíticas têm sido feitas entre estruturas nominais e reais de interação social, ou entre funções manifestas e latentes, mas elas derivam da observação do comportamento que é em grande parte expresso na língua falada.

A linguagem é apenas uma forma de comunicação e pode ser extraordinariamente ambígua e imprecisa, especialmente quando descreve sentimentos. Em geral, "as palavras marcam o processo pelo qual as espécies lidam cognitivamente com o seu ambiente" (Lenneberg 1967, 334), embora, às vezes, elas possam criar ideias em si mesmas. A linguagem 
também parece ser um desenvolvimento relativamente tardio na história cultural humana, embora seja admitidamente um fator crucial no comportamento da espécie, o que é o interesse de uma antropologia do corpo. Os seres anteriores que fizeram "machados" Acheuleanos tinham claramente um material cultural em comum e, portanto, um pensamento presumivelmente conceitual, e eles são considerados como humanos; mas é amplamente aceito hoje em dia que eles não falavam uma língua como nós a conhecemos. Assim, embora a linguagem seja certamente um ingrediente básico na história cultural do homo sapiens sapiens, as raízes dessa história, e talvez até mesmo a linguagem em si, foram estabelecidas junto a outros modos de comunicação (Ver, por exemplo, Hewes 1963, Livingstone 1973).

Fatores cruciais no desenvolvimento de formas culturais são a possibilidade de compartilhar estados somáticos, as estruturas dos corpos que os compartilham e os ritmos de interação que transformam experiências de sensações comumente internas em formas externas visíveis e transmissíveis. Esse processo, em teoria, não requer a linguagem falada ou mesmo conceitos linguísticos, apesar de, na prática, o uso da linguagem e suas consequências cognitivas serem parte integral da experiência de seres humanos normais. Os estados compartilhados de diferentes corpos podem gerar diferentes conjuntos de regras para a construção do comportamento e da ação através de movimentos repetidos no espaço e no tempo que podem ser transmitidos de uma geração para outra. Portanto, um número infinito de variações culturais é possível, com base nas variáveis dos estados somáticos compartilhados, movimentos do corpo, números e formas dos organismos envolvidos, dimensões do espaço e durações do tempo. o funcionamento eficaz dessas capacidades específicas da espécie pode ser restringido por limitações externas, como o entorpecimento dos sentidos ou as definições restritas de companheirismo humano demarcadas por alguns sistemas socioculturais. As propensões humanas para se relacionar com os outros em termos de respostas sentimentais e de cooperação ativa com as pessoas disponíveis são atenuadas desde a mais tenra idade. "Sentimentos" pelos outros são canalizados para domínios apropriados com base em status prescritos, papéis e situações sociais, ao invés de ser permitido que se desenvolvam de acordo com orientações interiores; e tentativas de cooperação são restringidas pelas demandas imperativas de outros que possuem maturidade física para controlar a interação social de acordo com seu próprio interesse. À medida que a criança se torna fluente na linguagem, a barreira entre as propensões biossociais e as imposições culturais se torna cada vez mais aguda. Crianças que tentam, mas não têm permissão para chamarem seus pais pelos nomes pessoais que eles usam para falar um com o outro, podem encontrar dificuldade de amar e reagir espontaneamente mesmo quando forem encorajadas a isso, 
porque elas aprenderam que os afetos individuais devem ser moderados por relações de autoridade. Entretanto, isso não torna os pais estranhos à criança, porque outros de quem as crianças podem igualmente gostar são definidos como distantes e essa classificação nominal reforça a presença física real do grupo próximo e concentra o impulso afetivo.

Estados somáticos compartilhados são consequências do sistema sensorial e comunicativo da espécie humana que é a condição básica para a interação social. Telepatia e empatia corporal, por exemplo, não são algo paranormal mas normal, embora sejam habitualmente suprimidos ou deixados para atrofiar em culturas que dão importância excessiva à comunicação verbal. Assim que as pessoas começam a analisar certos tipos de experiência, começam a notar que estas acontecem com muita frequência para serem coincidências. Por exemplo, alguém pode sentir desejo de telefonar para outro e, quando se aproxima do telefone, este toca e quem está ligando é aquele para quem a pessoa ia ligar. Eu diria que essa é uma expressão especial da conexão geral entre o homem e seus companheiros na qual um poderoso sentimento é traduzido em ação social. Um bom exemplo de situação oposta, o efeito da interação social sobre os estados somáticos, é discutido por Tiger (1975), que cita o relato de Martha Mcclintock sobre um "crescimento significativo na sincronização" do início da menstruação entre companheiras de quarto e amigas próximas.

\section{IV}

A segunda premissa de uma antropologia do corpo é que todo membro normal da espécie possui não só um repertório comum de estados somáticos e um potencial comum para estados alterados de consciência que têm sido classificados, especialmente por psicólogos humanistas, como parte do comportamento humano normal (Ver, por exemplo, Rowan 1976), mas também as mesmas propriedades específicas da função cognitiva. Devemos distinguir entre performance e competência, entre o que as pessoas fazem e o que elas são capazes de fazer. Se alguns seres humanos podem performar certas habilidades, deveria ser possível para qualquer membro da espécie fazê-lo, dado o ambiente social e cultural apropriado e oportunidades e incentivos similares. Esta é uma consequência lógica do princípio amplamente aceito da unidade psíquica da espécie humana, mas suas implicações geralmente não são investigadas. Até Lévi-Strauss sucumbe às visões elitistas da sua própria cultura quando argumenta que enquanto qualquer pessoa razoavelmente educada pode escrever poesia, a composição da música requer dons especiais que não são comuns a todos os membros da espécie (Lévi-Strauss 1964, 26). 
Os fundamentos biológicos e as formas culturais da linguagem fornecem um modelo que pode ser útil para analisar outros campos da ação humana. Todos os seres humanos normais podem falar uma linguagem natural, e há evidências para sugerir que a competência musical é, da mesma forma, baseada em capacidades específicas da espécie, apesar da incidência da performance musical variar consideravelmente entre uma sociedade e outra (Blacking 1971; 1973). Comportamento humano é aquilo que os humanos fazem, e muita coisa que um humano sente pode ser sentida por outro. O principal problema é identificar domínios significativos do comportamento social, e é nesse sentido que os limites biológicos (como na linguagem) podem ser comparados de maneira útil às "categorizações de diferentes áreas de comportamento" das sociedades e dos antropólogos. Isto é, claramente há um domínio da linguagem que pode ser parcialmente isolado biológica e culturalmente. Mesmo que outros domínios como política, religião, música, parentesco ou vida econômica sejam reconhecidos em todas as categorias culturais das sociedades, precisamos saber como tais categorias se relacionam com conjuntos diferentes ou relacionados de funções biológicas, se é que se relacionam, e, acima de tudo, com tipos de experiências compartilhadas que podem existir entre os seres humanos.

A primeira e a segunda premissa podem ser unidas para produzir duas proposições relacionadas. No mundo compartilhado da cultura e da sociedade, e permitindo certas limitações impostas pela diferenciação sexual, o que um organismo humano pode fazer, qualquer organismo pode fazer; mas nenhum humano pode fazer nada, ou mesmo se tornar humano, sem companheiros humanos. Comportamento humano e ação são extensões de capacidades que já estão no corpo, e as formas e o conteúdo dessas extensões são gerados por padrões de interação entre corpos no contexto de diferentes ambientes físicos e sociais. A questão surge imediatamente: se há habilidades humanas básicas derivadas de capacidades específicas da espécie, porque elas não emergem ontogeneticamente em todos os membros da espécie, como a linguagem? Eu sugiro que, como na linguagem, tais habilidades podem ser programadas para um cronograma de amadurecimento e, se não forem utilizadas na sociedade no momento apropriado, podem ficar atrofiadas.

Necessitamos observar o ambiente social preciso para a emergência das chamadas crianças-prodígio, por exemplo, assim como se seu desenvolvimento foi normal em lugar de excepcional. Assim, podemos aprender mais sobre as condições e estágios ótimos para aprender determinadas habilidades. Alguns sistemas educativos foram baseados nessas teorias e, mais recentemente, o método Suzuki demonstrou que a aprendizagem socializada do violino em idades muito precoces pode produzir resultados extraordinários. 
Isso leva à questão "o que é um ser humano normal?". Às vezes, argumenta-se que o progresso significativo na evolução das culturas, especialmente em atividades chamadas "artes", tem sido frequentemente feito por pessoas que não são apenas desviantes, mas que foram ou deveriam ser descritas como anormais. Dentro da antropologia, tem havido debates sobre supostas doenças mentais que encontram expressão institucional na mediunidade espiritual ou em certas profissões. Foi até alegado por um psiquiatra que o "fazer-se de louco" (Ukuthwasa) dos Xhosa que precede ao treinamento e frequentemente a uma carreira de sucesso na medicina tradicional, é evidência de anormalidade fundamental. Assim, ao discutir uma série de casos examinados, ele escreveu, por exemplo: "Evidência de loucura na família: seu pai e avó eram doutores!" Embora haja diferentes definições de normalidade tanto dentro da profissão médica quanto em diferentes culturas, eu tomo como normal qualquer ser humano que não tenha a infelicidade de nascer com um sério impedimento físico que incorreria em classificações médicas como retardado mental, surdo-mudo ou paralisado, e requerer cuidados especiais.

Mais um problema, o qual não estou qualificado para discutir em detalhe, é a distinção entre variação genética individual normal e uma mutação anormal. Eu não desafiaria a noção de mutação como uma possível explicação para certos seres humanos excepcionais, mas tais exceções não são de muito interesse para a antropologia, como ciência da cultura, a menos que a mesma mutação ocorra muitas vezes e seja uma condição necessária para um traço cultural particular. Por exemplo, foi sugerido (Smith e Worthington 1967) que Nicolo Paganini sofria um distúrbio hereditário no tecido conetivo, como a síndrome de Ehlers-Danlos ou de Marfan, que teria contribuído para as inovações que fez na técnica do violino. Uma vez realizadas por esse homem com um corpo extraordinário, elas se tornaram parte do repertório técnico dos virtuosos, e de fato nenhum dispositivo realmente novo para o violino foi inventado desde sua época. Mesmo que esse diagnóstico esteja correto e o distúrbio tenha sido causado por um gene, é uma mera curiosidade, já que centenas de violinistas puderam tocar a música de Paganini sem sofrer essa desordem física. A "singularidade" do corpo de Paganini é significativa no desenvolvimento da cultura apenas no modo como um sonho ou um voo de imaginação gera um poema ou uma nova máquina. As mesmas inovações poderiam ter sido feitas por qualquer violinista imaginativo, e o fato de não serem não prova necessariamente que seu inventor era significativamente anormal. De fato, pode-se argumentar exatamente 0 oposto: que ele forçou suas capacidades humanas normais ao máximo

6. Tradução livre da expressão "antic disposition". Segundo Michael Creamer, "antic disposition" na expressão de Hamlet de Shakespeare, significa fingir que se está perdendo a cabeça. Sob o pretexto de insanidade, ele sabe que terá licença para dizer e fazer coisas inesperadas e de outra maneira concernentes. Disponível em: https://bit.ly/2V5U3nL [N. T.]. 
ao tocar violino, como os violinistas subsequentes foram compelidos a fazer, de modo que o que era extraordinário para o tempo de Paganini é agora esperado para qualquer violinista de primeira linha.

Uma vez que todos os indivíduos são biologicamente únicos, o que é mais interessante na análise da cultura são as experiências e ideias que as pessoas podem realizar e compartilhar. Mozart foi sem dúvida um indivíduo notável, mas o que é mais interessante sobre ele é que ele era tão extra-ordinário, com tanto controle sobre suas capacidades humanas, que ele pôde ressoar em milhões de outros humanos de diferentes épocas e culturas.

Claramente alguns comportamentos sociais (ou mais frequentemente antissociais) são idiossincráticos e podem ser provocados por estados somáticos que se estendem desde uma dor de estômago a um ataque epiléptico. Idiossincrasias somáticas são de interesse de uma antropologia do corpo somente se precisarem ser invocadas para explicar a ação de uma pessoa numa situação social particular, ou se são tomadas por um grupo social como parte de sua cultura. Uma antropologia do corpo deve preocupar-se principalmente com estados somáticos e capacidades que os organismos normais podem compartilhar, seja por variedades de comunhão em grupo, ou pela experiência social em uma cultura comum.

$\mathrm{V}$

A terceira premissa de uma antropologia [do corpo] surge da primeira e da segunda premissa. Se a condição básica de uma sociedade humana é o estado generalizado de empatia que pode ser percebido através das sensações de organismos individuais, as formas de interação não-verbais são fundamentais. A cinésica e a proxêmica se interessam por aspectos microscópicos do movimento humano (Ver, por exemplo, Birdwistell 1970, Hall 1968), bem como pela demografia e pela genética de populações com os padrões de adaptação de grupos sociais maiores. Uma antropologia do corpo é o lugar de encontro entre o micro e o macro: sempre que possível, deve ser capaz de separar os movimentos do corpo de associações verbais e especificar os níveis nos quais os corpos respondem consciente ou inconscientemente à relação evolutiva da espécie e do seu ambiente em qualquer momento ou lugar.

Bateson sublinhou que "o discurso da comunicação não-verbal está precisamente voltado para questões de relacionamento - amor, ódio, respeito, medo, dependência etc. - entre o eu e o vis-à-vis ou entre o eu e o ambiente e [...] a natureza da sociedade humana é tal que a falsificação desse discurso rapidamente se torna patogênica" (Bateson 1973, 388). Categorias e sistemas de pensamento culturalmente prescritos, baseados 
em palavras, podem entrar em conflito com as informações que vêm de dentro do corpo e, assim, acumular tensões nos estados emocionais que encontram expressão no comportamento e na ação social.

Uma distinção útil pode ser traçada entre as formas rituais particulares de diferentes culturas e um modelo biológico universal que pode ser chamado de proto-ritual, um estado somático compartilhado do corpo social que produz tipos especiais de sentimentos e movimentos aparentemente espontâneos e interação entre corpos no tempo e no espaço. (A situação provavelmente não é biologicamente espontânea, embora pareça ser assim). Estados de proto-ritual podem ser comparados à ritualização de algumas espécies de animais, mas no homem eles são distintos por serem situacionais e não maturacionais. Isto é, há um "comportamento ritual específico da espécie e, portanto, adaptativo, do homem, distinto do comportamento ritualístico de alguns homens" que coordena no tempo todos os organismos que:

estão dentro de um espaço imediatamente observável e/ ou finalmente concebível [...] Experiências no tempo e no espaço são, portanto, externalizadas em uma situação externamente dada, de modo que teoricamente qualquer número de membros da espécie humana pode interagir ritualmente em qualquer momento da vida. Para a maioria dos rituais animais, a escolha do tempo e do local parece depender de fatores internos, como os estágios de maturação dos envolvidos. (Blacking 1976, 10)

A observação das formas culturais de tais estados mostra a transformação de expressões faciais individuais e movimentos corporais, e dos movimentos corporativos no espaço e no tempo dos corpos envolvidos. "Ondas" de sentimentos são geradas no corpo e entre corpos, não diferente de ataques de espirros ou soluços, e podem ser discernidas sequências discretas de tempo e padrões de movimento, análogas ao fluxo e refluxo de uma peça musical. Obviamente, as formas que os movimentos assumem são muito afetadas por sua estrutura cultural; mas, ao mesmo tempo (e especialmente em situações de culto coletivo quando as pessoas se submetem ao poder do espírito), emerge um padrão geral de interação e movimento, que, embora muitas vezes relacionado à experiência cultural, é moldado a partir do corpo e monitorado por padrões de fluxo de energia que transcendem as tentativas conscientes dos atores de manipular a situação. Em Natural Symbols, Mary Douglas afirmou que "a comunicação depende do uso dos símbolos" (Douglas 1973, 29), e particularmente dos símbolos da linguagem, e que "não pode haver organização sem expressão simbólica” (Op. cit., 73). Ela também argumentou que a emoção não é suscetível à divisão discreta. Nas situações proto-rituais às quais me referi, há um nível de comunicação e organização que ocorre sem linguagem e sem símbolos, e a emoção é 
frequentemente expressa em padrões contrastantes de movimento que são suscetíveis a uma divisão discreta. Ou seja, nem todos os eventos estão diretamente relacionados às categorias culturais compartilhadas, e deve ser possível distinguir as formas particulares do universal por meio de análises cuidadosas do movimento do corpo.

Clifford Geertz também rejeita a noção de uma tendência inata e pré-simbólica para ordenar a interação humana e estende o argumento além do campo da comunicação intencional para o sentimento:

Não dirigido por padrões culturais - sistemas organizados de símbolos significativos - o comportamento do homem seria virtualmente ingovernável, um mero caos de atos sem sentido e emoções explosivas, sua experiência virtualmente sem forma. (Geertz 1975, 46)

Sem os padrões de orientação da cultura humana[...] o homem, literalmente, não saberia como se sentir. (Geertz 1964, 47)

Talvez seja injusto citar Geertz sem fazer referência ao argumento de Susanne Langer: "em virtude de nosso pensamento e imaginação, temos não apenas sentimentos, mas uma vida de sentimentos" (Langer 1953, 372, grifo do autor). As afirmações de Geertz seriam mais aceitáveis se ele estivesse se referindo a uma vida de sentimentos em vez de sentimentos, e em outro contexto ele sugere que isto é assim: "A fim de decidirmos, devemos saber como sentir as coisas; e para saber como nós sentimos as coisas, precisamos das imagens públicas do sentimento que apenas 0 ritual, o mito e a arte podem proporcionar" (Geertz 1975, 82).

Retomando o argumento de Tomkins citado acima (Tomkins e Izard 1966, VII), é necessário distinguir entre sentimentos e uma vida de sentimento e, em particular, avaliar o impacto dos sentimentos no pensamento e na imaginação e reconhecer que mesmo as "emoções explosivas" não são respostas aleatórias e sem sentido. Karl Primbram (1967) também sugeriu que as emoções devem ser vistas como processos neurais que estruturam a recepção como alternativa à ação instrumental. Não é assunto de uma antropologia do corpo investigar como esses estados operam fisiologicamente, embora seja necessário reconhecer que, por serem situacionais, suas formas expressivas variarão de acordo com o tempo, o lugar e o número de pessoas envolvidas e que, embora surjam da aceitação da complexidade automática do corpo, eles não são "abandonados". É a sua própria repetição e concentração que os torna tão distintivamente humanos: por um tempo indeterminado, o mundo dos atores fica parado enquanto eles reagem uns aos outros e à permanência percebida de sua vida social, e não [reagem] à impermanência de sua existência anatômica. A qualidade realmente surpreendente sobre 
os seres humanos não é a mudança, mas a não-mudança, a capacidade de parar o mundo e repetir ações, para se desvincular do ambiente em constante mudança e do ciclo da vida.

É neste processo que rompe "o silencio primordial" sobre o qual Merleau-Ponty escreveu, e entre suas características que devem ser medidas pelos antropólogos estão seus tempos e padrões de movimento, pois são chaves para seus significados. Como Morton Marks demonstrou efetivamente em um estudo da música afro-americana (Marks 1974), o ritual enfaticamente não é comunicação sem informação. Tudo o que conhecemos sobre a mente dos animais não-humanos deriva da observação de seus movimentos, gestos e comunicação não-verbal: muito pode ser aprendido sobre o animal humano quando é estudado desta mesma forma.

Muitas das funções do corpo dependem da sequência e timing dos eventos, e um timing adequado é um sinal de boa saúde. Isso é particularmente verdadeiro no caso da linguagem, onde a maioria dos "distúrbios da fala e da linguagem de $\mathrm{SNC}^{7}$ pode ser caracterizada como um distúrbio dos mecanismos de timing" (Lenneberg 1967, 218; ver também 116ff). Métrica e coordenação rítmica são importantes na terapia da fala e, de forma mais geral, no tratamento de crianças com deficiência mental (Nordoff e Robbins 1971, 30 a 32 e 103). A pesquisa ainda não mostrou como os vários ritmos naturais do corpo se entrelaçam, mas há pouca dúvida de que o ciclo circadiano8 seja um importante princípio organizador na fisiologia humana (Luce 1973). Estes fenômenos são parte da complexidade automática do corpo, e na medida em que são apenas vagamente (se é que são) percebidos através de mudanças de sentimento, eles fazem parte "do silêncio primordial".

Ritmos biológicos podem influenciar sentimentos e performance, mas eles não necessariamente determinam a experiência de tempo: isso é uma consequência da codificação de eventos, em que a duração do tempo é percebida em relação à quantidade de informação processada ou rememorada (Ornstein 1969). Agora, a codificação de eventos é uma atividade essencialmente do corpo e particularmente do cérebro, que rompe o silêncio primordial. Torna-se possível por estados somáticos recorrentes em que o tempo parece estar parado.

Racionalizações de estados somáticos transcendentais e experiências de ressonância corporal variam de uma cultura para outra, tanto quanto

7. Sistema nervoso central [N. T.].

8. Nota dos tradutores: 0 Ciclo circadiano é o período de aproximadamente 24 horas sobre o qual se baseia o ciclo biológico de quase todos os seres vivos, sendo influenciado principalmente pela variação de luz, temperatura, marés e ventos entre o dia e a noite. É o ciclo que regula os ritmos fisiológicos e psicológicos do corpo humano, com influência sobre processos como a digestão ou o estado de vigília e sono, a renovação das células e o controle da temperatura do organismo. Ver: Merlin, Gegear e Reppert , 2009. 
os títulos que Rodin deu a uma escultura antes de encontrar um que o satisfizesse. Provavelmente por causa disso, as formas dessas "experiências máximas", altamente valorizadas, receberam menos atenção do que a "tagarelice das palavras" que as cercam. Os sistemas sociais são corretamente concebidos e estudados como sistemas de valores; mas sistemas de valores e níveis de concordância entre membros de uma sociedade não podem ser entendidos adequadamente apenas no nível verbal, seja através da racionalização de eventos pelos atores ou da observação acumulativa que os observadores fazem deles. As pessoas podem não apenas enganar os outros; elas podem se enganar em sua reificação de seus sistemas simbólicos e sociais. Por exemplo, um sistema de simbolismo corporal, embora pareça brotar das necessidades reais e da natureza do corpo, pode sutilmente expressar os interesses de um grupo dominante e tornar-se a camisa de força que inibe a autoexpressão e distorce a postura. De novo, os valores de um sistema social que podem parecer adaptativos no contexto de uma cultura particular podem ser biologicamente não-adaptativos, devido à falta de racionalização das forças biossociais; a força desse contraste entre valores reais e racionalizados geraria conflito. Como Maslow argumentou, "dicotomizar patologiza (e a patologia dicotomiza). Isolar duas partes inter-relacionadas de um todo umas das outras, partes que precisam umas das outras, partes que são verdadeiramente 'partes' e não totalidades, distorce as duas coisas, as adoece e contamina" (Maslow 1970, 13). Quando a "mente" é artificialmente separada do corpo, ou o pensamento é separado dos sentimentos e dos movimentos do corpo que os gera, as duas partes sofrem. Culturas são extensões e adaptações de sentimentos, e especialmente da humanidade (fraternidade), que são universais para as espécies, e se a base biológica do comportamento é ignorada ou desvirtuada, as leis da natureza devem inevitavelmente anular as tentativas do homem de escapar delas. Muitos conflitos surgem de inconsistências entre as forças sociais que ligam as sociedades humanas e as descrições culturais inadequadas do homem sobre as situações sociais.

Como podemos mensurar o aparentemente invisível, e como podemos presumir dizer que algo não reconhecido pelos atores é real? É tão real para fins explicativos como átomos, genes ou contagens diferenciais sucessivas de leucócitos: isto é, pode ser inferido de certos tipos de comportamento observável. Não é invisível: pode ser observado no colapso e transformação de organismos, como a morbidade e epidemiologia de uma comunidade, ou em mudanças nos gestos e posturas, especificamente na inconsistência de postura em encenação contrastante. Ekman e Friesen, em estudos de expressão facial e movimentos das mãos, mostraram como os padrões de movimento das pessoas variam nas doenças e na saúde, e como é possível detectar o fingimento do corpo ou da face (Ekman e Friesen 1973; 1974). 
Precisamos contrastar os movimentos de pessoas sujeitas a situações autoritárias com os movimentos que elas fazem em um ambiente familiar. Embora os padrões de movimento dos jamaicanos, paquistaneses e outros imigrantes possam variar em suas casas de acordo com certos traços culturais, nas situações oficiais dos escritórios de imigração, agências de emprego e delegacias de polícia, eles podem responder com conjuntos comuns de movimentos. Precisamos estudar os movimentos, gestos e contato corporal que bebês e crianças experimentam, pois essas experiências provavelmente exercem a mais profunda influência sobre o pensamento conceitual, o comportamento social, a saúde e o desenvolvimento de habilidades.

Ao mesmo tempo, devemos reconhecer a possibilidade, argumentada por Cicourel (apud Benthall e Polhemus 1975, 220ff), de que os modos de comunicação oral e gestual diferem cognitivamente, porque são dois sistemas de codificação alternativos para processos simbólicos verbais e imaginários visuais. Nesse aspecto, os processos de pensamento dos surdos podem fornecer evidências cruciais. Cicourel argumenta que 0 pensamento dos surdos envolve a linguagem, mas, como sugeri, seria de se esperar que tanto o pensamento oral quanto o gestual fossem aspectos de um sistema de movimento mais profundo do corpo.

VI

A quarta premissa de uma antropologia do corpo é que a mente não pode ser separada do corpo. Isso está ligado à terceira premissa, uma vez que é nessas áreas da comunicação não-verbal, especialmente a dança e a música, que podemos observar a mente trabalhando através do movimento dos corpos no espaço e no tempo. Além disso, é na verbalização e na mentalização do essencialmente não verbal, das artes manuais, que vemos o mais insidioso e desumanizado ataque ao desenvolvimento mais apurado do homem e da cultura. A dicotomia corpo/mente pode ser parcialmente explicada como um fenômeno cultural, como um artefato de certos modos de produção e formação sociais, refletindo a divisão do trabalho manual e mental na produção; mas também a evidência de que isso pode ser produto de um uso assimétrico do corpo que poderia, portanto, emergir mesmo numa sociedade verdadeiramente socialista na qual o trabalho manual e mental não são separados ou falsamente avaliados. Dança, música, pintura e escultura são verdadeiramente formas do trabalho manual não-verbal, mas foram investidas da "dignidade" de trabalhos "quase-mentais": o artista "fala" aos mortais inferiores sobre coisas elevadas e, portanto, sua consciência é distinta de sua prática manual. Isso sustenta o argumento burguês da diferenciação de classe, ou seja, que uma classe deve realizar o trabalho manual para que a outra possa cuidar das necessidades mentais na sociedade. Assim, mesmo 
onde o modo de produção é refletido numa separação ideológica entre corpo e mente, a sociedade admite a importância de uma forma de atividade que é ao mesmo tempo manual e mental, realizando a mediação entre o mundo da produção e o mundo do pensamento e das construções mentais. A questão levantada é em que medida tais "artes" são parte de uma superestrutura ideológica da vida social necessária para resolver contradições criadas pela divisão entre o trabalho manual e o mental e em que medida elas são uma forma especial de trabalho manual, e ainda, por que elas existem afinal nas suas formas contemporâneas ou por qual razão chegam mesmo a existir.

Se, como produtos do trabalho mental, elas são instrumentos da auto-definição do desenvolvimento dos sentidos do homem, são somente parte de uma fase da história humana que vai passar quando o "não-trabalho de poucos" deixar de ser uma condição "para o desenvolvimento geral das potencialidades da mente humana (Marx 1973, 705). Quando o homem se apropriar de seus sentidos e "superar a alienação de sua verdadeira essência [...] a Arte como tal será suprimida, uma vez que Arte e Vida terão se tornado uma só" (Hess 1973, 313). Se "as ideias não existem em separado da linguagem", então, de fato, as Artes como tal desaparecerão quando as ideias que elas expressam forem trabalhadas através da resolução das contradições sociais. Mas, se o propósito das artes é refletir ideias através de tipos diferentes de trabalho manual "artístico", por que deveriam usar modos não-verbais de comunicação? Por que tentar "dizer" através de dança ou música o que pode ser igualmente ou melhor dito em palavras? Música, por exemplo, não é uma linguagem imediatamente compreendida a ponto de se esperar que ela produza respostas específicas, já que é a expressão metafórica de sentimentos. Ela não pode comunicar nada de novo a seus ouvintes além de padrões de som não familiares que, por meio de contrastes rítmicos e tonais, pode despertar tensão nervosa ou impulso motor -dado que são apresentadas em um ambiente cultural familiar enquanto comportamento percebido como musical. Por que a música deveria ter valor vital se ela é meramente reflexo das contradições inerentes da divisão entre o trabalho manual e mental?

É precisamente porque dança e música são modos não verbais de comunicação especiais que elas têm valor na sociedade humana.

Pesquisas recentes têm sugerido que na lateralização das funções do cérebro:

o hemisfério esquerdo é predominantemente envolvido com o pensamento analítico, especialmente linguagem e lógica. Esse hemisfério parece processar a informação sequencialmente [...] o hemisfério direito, por contraste, parece ser primordialmente responsável pela nossa orientação no espaço, talentos artísticos, consciência corporal e reconhecimento 
facial. Ele processa informações de modo mais difuso do que o hemisfério esquerdo, integra material e simultaneamente ao invés de linearmente. (Ornstein 1973, 87)

A especialização dos dois hemisférios parece ser única aos seres humanos e está relacionada a evolução da linguagem [...] os trabalhos complementares de nossos dois processos de pensamento permitem nossas maiores conquistas, porém a maior parte das ocupações valoriza um modo em detrimento do outro [...] uma consciência humana completa deveria incluir ambos os modos de pensamento. (Op. cit. 92, grifo nosso)

A dicotomia corpo/mente pode, desse modo, ser vista como uma extensão do corpo, expressando simbolicamente as funções separadas dos hemisférios esquerdo e direito do cérebro. Pelo fato de grande parte da vida social ser dominada pela linguagem e pelo pensamento linear, as artes são necessárias não meramente no nível ideológico, como mediadoras entre o trabalho mental e manual: elas têm a função biológica de ativar ambos os hemisférios do cérebro e assim contribuir com uma consciência humana mais completa. Algumas capacidades musicais parecem estar localizadas no hemisfério direito, enquanto outros aspectos segmentares das estruturas musicais certamente derivam de operações do lado esquerdo do cérebro. Se isso for verdade, então a música é uma coordenadora particularmente apropriada das atividades cerebrais.

As consequências da lateralização das funções do cérebro são valores desiguais atrelados ao trabalho mental e manual, que podem ser reforçados ou reduzidos de acordo com as sociedades e com a ênfase dada por elas às diferentes atividades corporais. Entretanto uma vez que, sob circunstâncias ideais (ou normais?), ambos os hemisférios deveriam ser plenamente operacionais, há sempre a possibilidade de que tais estados somáticos "abertos" possam ocorrer espontaneamente e afetar um corpo-mente até então fechado, mesmo em uma sociedade em cujos padrões de construtos mentais e atividades corporais tenham alta tendência a ser contrários a isso.

A obscura dicotomia mente/corpo oferece uma rota de fuga conveniente para muitos problemas difíceis, tais como explicar conceitos como misericórdia, piedade, verdade e justiça em termos evolutivos. Como poderiam tais conceitos ter evocado sentimentos realmente profundos das pessoas, longe de serem descompromissados, se não tivessem algum tipo de valor adaptativo para a espécie? Como tais conceitos poderiam ser alienados de sentimentos, ou mesmo vieram a existir, sem fundamentações biológicas? Teria como serem inventados se nunca tivessem sido sentidos em primeiro lugar? Se dissermos que esses conceitos são, em sua maioria, criações autônomas da mente, não precisamos fazer 
perguntas embaraçosas: todas elas podem estar relacionadas a situações sociais reais, e podem até ser vistas como ideias que surgem de respostas auto-interessadas e estratégicas aos problemas sociais. (Por exemplo, eu invento e invisto de valor a ideia de compaixão quando um prisioneiro de guerra, que deveria ter sido morto, me salva da morte). 0 importante denominador comum é o modo como os corpos das pessoas respondem em determinadas situações, e não as supostas ginásticas mentais pelas quais os mesmos conceitos podem ter chegado em diferentes sociedades e culturas. Se a sociedade é vista como um sistema de forças ativas na qual todos os corpos são altamente sensíveis aos sentimentos de outras pessoas, então compaixão, piedade, verdade e justiça podem ser entendidas como sentimentos distintos, com conceptualizações correspondentes, que surgem quando experiências primordiais e biologicamente necessárias de empatia são afrontadas de alguma maneira.

A patológica dicotomia mente/corpo também se reflete nas conceituações culturais contraditórias da experiência física. Por exemplo, "enamorar-se" e "estar apaixonado" são geralmente distintas de "fazer sexo" como formas superiores de uma atividade essencialmente animal. "Apaixonar-se" geralmente se refere a uma associação entre corpos da qual se espera que envolva mais do que a mera atração sexual, e pode ser descrita como atividade do corpo que depende de sentimentos para com outro corpo; "fazer sexo" diz respeito a uma situação em que um parceiro pode realizar atividades sexuais de forma adequada e prazerosa enquanto pensa em outra coisa ou outra pessoa, e pode ser descrita como uma atividade treinada pela mente que se baseia em conceitos sobre mulheres, masculinidade, sexualidade e assim por diante. Curiosamente, para uma sociedade que acredita em uma mente superior ao corpo, exaltamos momentos nos quais acreditamos que a mente é absorvida no corpo, em contraste com um ato sexual no qual a mente pode estar separada do corpo.

Meu interesse numa antropologia do corpo está na convicção de que sentimentos, particularmente os de empatia expressados através do movimento dos corpos no espaço e no tempo, geralmente sem conotações verbais, são a base da vida mental. Se as antigas ferramentas acheuleanas são uma evidência sobre uma nova forma de pensar, é porque são, primeiramente, produtos de novas formas de sentir e mover o corpo. A característica mais surpreendente desses antigos artefatos não é sua função como instrumentos de produção, mas sua forma, como produtos de um ser que demonstra um senso de ordem que poderia ser chamado de "estético" ou "artístico". Eles refletem concentração, um sistema padronizado de execução, movimentos corpóreos repetidos no espaço e o tempo e uma continuidade de estilo que sugere uma cultura comum, mas acima de tudo, uma sensibilidade para a forma. 
J. Z. Young afirmou que a criação de novas formas estéticas "tem sido a forma mais fundamentalmente produtiva de todas as atividades humanas. Quem quer que crie novas convenções artísticas encontra métodos de intercâmbio entre pessoas relativos a questões até então incomunicáveis. A capacidade de fazer isso tem sido a base de toda a história humana" (Young 1971, 519). Gregory Bateson salientou que "sem a ajuda da arte" a consciência "nunca pode experimentar [...] a natureza sistemática da mente" (Bateson 1973, 118). A função essencial do processo artístico é mediar entre o impermanente e o permanente no homem para capturar a força do sentimento com formas que sempre devem começar como extensões do corpo. Se a criação de uma nova forma estética for produto do pensamento consciente. Eu acho que a maioria dos artistas criativos vai concordar que o processo começa como uma "explosão" do corpo que produz resultados aparentemente espontâneos.

o uso de formas espelhadas em música e dança proporciona o exemplo mais interessante de "explosão" do corpo, porque são formas que o homem nunca poderia descobrir, a não ser através de seu corpo. Existe uma sequência lógica que vai da observação das formas espelhadas na natureza à sua utilização em design, mas não ao seu uso na música e na dança. Se, no entanto, transformações espelhadas fazem parte das funções cognitivas do corpo, elas poderiam ser aplicadas criativamente em qualquer campo sem observações ou experiências prévias, como na dança e na música. Eles poderiam ser uma estrutura biológica básica, responsável pelas formas espelhadas no corpo humano e na natureza em geral. Também é possível que a percepção e a criação de transformações espelhadas emerjam apenas através da experiência de interação social. O mais significante é que podem ambas ser sentidas e usadas em nível inconsciente (Schoenberg 1951), e podem ser fatores importantes na comunicação musical. Ou seja, mesmo quando compositores exercitam conscientemente suas mentes para produzir uma estrutura musical unificada, os toques finais de seu trabalho são geralmente dados por seus corpos; e é porque um corpo humano cria uma ordem simbólica com um mínimo de interferência "cultural" que a musica ressoa para uma larga variedade de pessoas que podem compartilhar pouco ou nada das experiências prévias do compositor (Cf. Reti 1961; Walker 1962). A música pode não obedecer às regras do conservatório, mas as plateias vão senti-la no fundo do coração, porque refletem o que Bateson chama de "algoritmos do coração" (Bateson 1973, 112).

Embora música e dança sejam formas de comunicação não-verbal, elas são sempre fatos sociais e, portanto, nunca podem ser completamente livres dos conceitos verbais e construções de realidade que predominam em diferentes sociedades. Não é simplesmente que as palavras possam ser musicadas e assim afetar sua estrutura, mas que as "linguagens" da 
música e da dança podem ser necessárias para expressar outros conjuntos de símbolos, e essa música e dança podem ser precisamente distintas da não-música e não-dança. No entanto, é possível demonstrar (Cf. Ruwet 1972; Blacking 1974) que existem formas intrínsecas à música e à dança que não são modeladas na linguagem. Podemos olhar além das "linguagens" da dança, por exemplo, para as danças da linguagem e do pensamento.

Assim como o movimento consciente está em nossos pensamentos, pensar pode vir do movimento, especialmente o pensamento compartilhado ou conceitual advindo do movimento comum (Blacking 1976). E assim como o objetivo final da dança é a possibilidade de danças sem pensar, ser dançado, a conquista final do pensamento é ser movido a pensar, ser pensado. Às vezes chamam isso de inspiração, insight, genialidade, criatividade e por aí vai. Mas essencialmente é uma forma de celebração inconsciente, um movimento do corpo. Somos movidos ao pensamento. Mente e corpo são um.

Uma objeção imediata à noção de que o conceito de mente é de fato um modo de falar sobre o corpo social do homem, mais do que um fenômeno quase autônomo, vem da evidência que sugere que o elemento moral é um fator crítico em muitas atividades e experiências corporais. Já mencionei o andar sobre o fogo, sobre o que às vezes se diz ser uma conquista da mente sobre o corpo ou a matéria. Em campos mais mundanos, proezas atléticas ou habilidades pianísticas parecem depender de proporções apriorísticas do corpo, e ainda qualidades misteriosas como determinação ou vontade podem ajudar um corpo menos adequado a performar melhor do que o esperado. Explicações similares sobre sobrevivência e recuperação são sempre oferecidas em casos de enfermidades agudas, ou mesmo de resfriados.

Quando a complexidade automática do corpo e particularmente do corpo social for melhor compreendida, vai ficar evidente que muitas das situações em que a mente se sobrepõe ao corpo podem ser explicadas em termos biossociais. Primeiramente, na doença, os efeitos puramente físicos da concentração de fluxo de energia de outras pessoas pode fazer mais por um paciente do que a sua própria "vontade" e, em segundo lugar, a atividade física incidental a um esforço da "mente" provavelmente faz mais do que qualquer outra coisa para processo de cura do corpo; e se o corpo está fora de recuperação, toda vontade do mundo provavelmente não vai ajudar. Nos hospitais modernos, a importância de se mover corpos doentes, mesmo logo após uma operação extenuante, é agora reconhecida em geral; uma série de estudos por James Prescott e outros mostraram a importância do movimento, do toque e da experiência sensória no desenvolvimento mental (Ver Prescott 1971). Há também muitas atividades físicas, como dança e música coletivas que 
geram mais do que redução da energia física. Além disso, o segredo de muitas técnicas de atletismo, ginástica e música é encontrada no relaxamento e ritmo, deixando o corpo fazer seu próprio trabalho após um período de prática - o que é certamente o oposto da mente sobre o corpo!

A meu modo de ver, a antropologia do corpo não busca por bases instintivas do comportamento, e certamente não contrapõe instintos ao pensamento conceitual e à linguagem verbal, como Konrad Lorenz parece fazer (Lorenz 1967, 29). Busca antes uma melhor compreensão dos princípios gerais da ação humana através do estudo das variações culturais em relação às propensões e restrições biológicas e os quadros gerais da evolução. Estou particularmente interessado nas capacidades comportamentais que, como a fala, combinam especificidade com plasticidade, e com a possibilidade de que muitas capacidades humanas sejam melhor desenvolvidas, e talvez somente capazes de desenvolvimento durante períodos específicos de crescimento do organismo.

Estou interessado no que Alland chama de imperativo humano, mas eu não compartilho sua visão de que o sistema cognitivo sobre o qual o comportamento humano de alguns grupos específicos é baseado, "consiste em classificações nas quais o campo ambiental (incluindo outros seres humanos) é dividido de acordo com um sistema arbitrário, porém tradicional. Fora deste sistema de classificação se desenvolve um conjunto de regras para a ação" (Alland 1972, 152, grifo nosso). O caso da música, que Lévi-Strauss chamou de "o supremo mistério da ciência do homem” (Lévi-Strauss 1964; Ver também Blacking 1975) me convence de que pelo menos essa área da ação humana segue regras que estão longe de serem arbitrárias, não importando o quão arbitrária a visão de música e não-música e outros aspectos do sistema de classificação possam parecer ser. Além disso, as estruturas profundas do comportamento musical podem geralmente ser medidas com um grau satisfatório de objetividade. Por exemplo, se tomarmos uma grande amostra de performances do mesmo instrumento de diferentes músicos dentro da mesma tradição, e também descobrirmos com artistas e audiências de quem e onde as melodias foram aprendidas e de onde elas se originaram, poderemos comparar as variações dessa performance musical com classificações e percepções populares. Podemos então achar que mesmo que um grupo de violinistas irlandeses alegue ter sido influenciado por um indivíduo em particular que vem do Condado de Donegal ou County Clare, sua residência continuada em Country Tyrone os influenciou a desenvolver estilos que traem as características dessa região. Suas percepções da música per se poderiam ser mais detalhadamente testadas, pedindo-lhes para identificar a proveniência de uma série de gravações, e observar se suas respostas mostram consistência no reconhecimento de estilos individuais ou locais. 
O estudo dos sentimentos, dos sistemas de comportamento não-verbal e das extensões do corpo na cultura acrescenta dimensões importantes para o arsenal dos antropólogos sociais. Isto pode revelar padrões de interação mais fundamentais e duradouros entre os corpos sociais e seu ambiente, que transcendem o que parece estar pressionando mais imediatamente as realidades socioeconômicas. Eu fui acusado de escolher um tópico irrelevante para um estudo antropológico sério, escandalosamente inadequado para uma conferência na Irlanda do Norte em 1975. Se eu sentisse que havia alguma atitude que eu pudesse tomar para aliviar a fome do mundo, a exploração econômica, a opressão de classe ou o racismo a última coisa que eu faria seria convocar uma conferência de antropologia para falar sobre isso. Em geral eu aceito as críticas ao viés colonialista em nossa disciplina e saúdo a atual preocupação com a situação de minorias étnicas, com problemas de desenvolvimento, e com a aplicação da teoria dos modos de produção aos dados antropológicos. Todos esses assuntos são muito importantes, mas não os considero problemáticos: eles parecem exigir ação política em vez de discussão teórica. o que se tornou problemático para mim nos últimos anos é a questão de quanto controle o homem tem sobre seu próprio destino e até que ponto sua liberdade cultural é contida por restrições biológicas e evolucionárias. Na reestruturação de nosso sistema educacional e na criação de uma sociedade verdadeiramente igualitária em que todo o potencial de cada ser humano possa ser desenvolvido, é necessário saber que propensões, que capacidades e que sensibilidades podem ser liberadas e em que fases da vida elas devem ser cultivadas. Isso requer um entendimento mais completo do corpo social porque, como todo mundo já aprendeu em algum momento pela experiência, é somente quando colocamos nossas aquisições culturais em harmonia com as forças e estruturas de nossos corpos e aceitamos as suas condições, que temos a liberdade de viver criativamente. 0 primeiro passo para a conquista de nossos sentidos em uma sociedade verdadeiramente livre é a compreensão das limitações e possibilidades de corpos individuais e sociais. E isso é uma das principais razões pelas quais estou interessado na pesquisa da antropologia do corpo.

\section{AGRADECIMENTOS}

Eu sou muito grato a Brenda Beck, Zureena Desai, Hilary Paul Ekman, Roy Willis e colegas do meu departamento, pelas críticas de rascunhos anteriores deste artigo.

\section{REFERÊNCIAS}

Alland, A., Jr. 1972. The Human Imperative. New York: Columbia University Press.

Bateson, G. 1973. Steps to an ecology of mind. Paladin.

Benthall, J. and Polhemus, T. (eds.) (1975). The Body as a medium of expression. London: Allen Lane.

Birdwhistell, R. L. 1970. Kinesics and context: essays on body motion communication. Philadelphia: University of Pennsylvania Press. 
Blacking, J. 1971. Towards a theory of musical competence. In E.J. de Jager (ed.) Man: Anthropological essays presented to O.F. Raum. Capetown: C. Struik, 19-34.

Blacking, J. 1973. How musical is man? Seattle: University of Washington Press.

Blacking, J. 1974. Ethnomusicology as a key subject in the social sciences. In: In memoriam Antonio Jorge Dias, Vol. III, Lisbon, 71- 93.

Blacking, J. 1976. Dance, conceptual thought and production in the archaeological record. In G. de G. Sieveking, I.H. Longworth and K.E. Wilson (eds.), Problems in economic and social archaeology, Londn: Duckworth, 3- 13.

Douglas, M. 1973. Natural symbols: explorations in cosmology. Pelican Books.

Durkheim, E. 1961. The elementary forms of the religious life. (tr. J.W. Swain). New York: Collier Books.

Eibl-Eibesfeldt, I. 1971. Leve and hate (tr. Geoffrey Strachan) London: Methuen.

Ekman, P., Friesen, W.V. and Ellsworth, P. 1972. Emotion in the human face. Elmsford, New York: Pergamon.

Ekman, P. and Friesen, W. V. 1973. Nonverbal behavior and psychopathology. In R. J. Friedman and M.M. Katz (eds.), The Psychology of Depression: Contemporary Theory and Research, 203-231.

Ekman, P. and Friesen, W. V. 1974. Detecting deception from the body or face. Journal of Personality and Social Psychology, 29 (3): 288-298.

Ekman, P. and Freisen, W.V. 1975. Unmasking the face: a guide to recognizing emotions from facial cues. New Jersey: Prentice-Hall.

Fox, R. (ed.) 1975. Biosociai anthropology. ASA Studies. London: Malaby Press.

Geertz, C. 1964. The transition to humanity. In Sol Tax (ed.), Horizons of anthropology, London: Allen and Unwin, 37-48.

Geertz, C. 1975. The interpretation of cultures. London: Hutchinson (c. 1973).

Hall, E.T. (1968) Proxemics. Current Anthropology, 9 (2 - 3): 83- 108.

Hess, H. 1973. Is there a theory of art in Marx? Marxism Today, October.

Hewes, G.IL 1973. Primate communication and the gestural origin of language. Current Anthropology, 14 (1-2): 5-24.

Hinde, R. 1972. Non-verbal communication. Cambridge University Press.

Langer, S. 1953. Feeling and form. London: Routledge and Kegan Paul.

Lenneberg, E.H. 1967. Biological Foundations of Language. New York: Wiley.

Levi-Strauss, C. 1964. le cru et le cuit. Paris: Plon Livingston, F. 1973. Did the australopithecines sing? Current anthropology 14 (1-2): 25- 29.

Lorenz, K. 1967. On Aggression. New York: Bentham Books.

Luce, G. C. 1973. Body time: the natural rhythms of the body. Paladin.

Marks, M. 1974. Uncovering ritual structures in Afro-American Music. In Irving.

Zaretsky and, P. Leone (eds.) Religious Movements in Contemporary America, Princeton University Press.

Marx, K. 1973. Grwidrisse (tr. Martin Nicolaus). Penguin Books.

Maslow, A.H. 1970. Religions, values, and peak-experiences. New-York: Viking Compass Book. 
Mauss, M. 1936. Les techniques du corps. Journal de la psychologie, 32.

McClintock, M. 1971. Menstrual synchrony and suppression. Nature, 229, 244-245.

Merleau-Ponty, M. 1962. Phenomenology of Perception (tr. Colin Smith). London: Routledge and Kegan Paul.

Nordoff, P. and Robbins, C. 1973. Therapy in music for handicapped children. London: Gollancz.

Ornstein, R.E. 1969. On the experience of time. Penguin Books.

Ornstein, R.E. 1973. Right and left thinking. Psychology Today, flay: 87-92.

Poole, R. 1965. Objective sign and subjective meaning. In Jonathan Benthall and Ted Polhemus (eds.) The body as a medium of expression: 74-104.

Prescott, J.W. 1971. Early somatosensory deprivation as an ontogenetic process in the abnormal development of the brain and behaviour. In I.E. Goldsmith and J. MoorJankowski (eds.), Medical Primatology. 1970, Basel: S. Karger, 356-375.

Pribram, K.H. 1967. To a new neurology and the biology of emotion: a structural approach. American Psychologist, 22: 830-838. Reprinted in K.H. Pribram (ed.), Brain and behaviour, Penguin Books (1969): 452-466.

Reti, R. 1961. The thematic process in music. London:Faber and Faber.

Rowan, J. 1976. Ordinary ecstasy: humanistic psychotogy in action. London: Routledge and Kegan Paul.

Ruwet, N. 1972. Langage, musique, poésie. Paris: Seuil.

Schoenberg, A. 1951. Style and idea . London: Williams and. Norgate.

SIIII.th, R.D. and Worthington, J.W. 1967. Paganini: The riddle and connective tissue. Journal of the American Medical Association, 199 (11): 820-824.

Tiger, L. 1975. Somatic factors and social behaviour. TnR. Fox (ed.), Biosocial anthropofogy.

Tomkins, S.S. and Izard, C.E. (eds.) 1965. Affect, cognition, and personality. London: Tavistock.

Walker, A. 1962. A study in musicai analysis. London:Barrie and Rockl iff.

Washburn, S.L. and Howell, F.C. 1960. Human evolution and culture. In S. Tax (ed.), The evoiution of man, Chicago University Press.

White, L.A.1949. The Science of CuZture. New York: Farrar, Straus and Cudahy.

Young, J.Z. 1971. An introduction tc the study of man. Oxford: at the Clarendon Press.

JOHN BLACKING (1928-1990) buscou compreender a importância da música na cultura e no desenvolvimento humano ao longo de sua carreira. Com formação em música, e transitando entre antropologia e etnomusicologia, produziu uma vasta quantidade de publicações sobre a musicalidade do povo Venda, habitante do norte do Transvaal, na África do Sul, com especial atenção ao desenvolvimento musical de suas crianças. Essa pesquisa Ihe rendeu o título de doutor pela University of the Witwatersrand em 1965. Dentre os seus propósitos, estava o de compreender música como força social e cultural, o que permeou tanto seu trabalho etnográfico quanto sua prática de ensino, majoritariamente desenvolvida na Queen's University Belfast, na Irlanda do Norte, bem como em suas pesquisas. Blacking também é uma referência no campo da educação musical.

Licença de uso. Este artigo está licenciado sob a Licença Creative Commons CC-BY. Com essa licença você pode compartilhar, adaptar, criar para qualquer fim, desde que atribua a autoria da obra. 